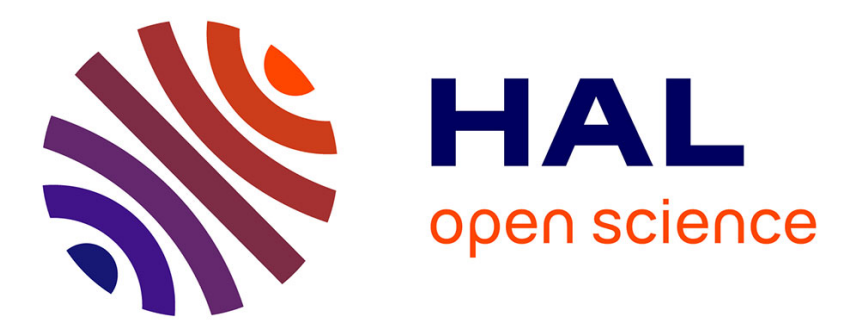

\title{
Modelling the potential spread of Fusarium circinatum, the causal agent of pitch canker in Europe
}

Timo Möykkynen, Paolo Capretti, Timo Pukkala

\section{To cite this version:}

Timo Möykkynen, Paolo Capretti, Timo Pukkala. Modelling the potential spread of Fusarium circinatum, the causal agent of pitch canker in Europe. Annals of Forest Science, 2015, 72 (2), pp.169-181. 10.1007/s13595-014-0412-2 . hal-01284164

\section{HAL Id: hal-01284164 \\ https://hal.science/hal-01284164}

Submitted on 7 Mar 2016

HAL is a multi-disciplinary open access archive for the deposit and dissemination of scientific research documents, whether they are published or not. The documents may come from teaching and research institutions in France or abroad, or from public or private research centers.
L'archive ouverte pluridisciplinaire HAL, est destinée au dépôt et à la diffusion de documents scientifiques de niveau recherche, publiés ou non, émanant des établissements d'enseignement et de recherche français ou étrangers, des laboratoires publics ou privés. 


\title{
Modelling the potential spread of Fusarium circinatum, the causal agent of pitch canker in Europe
}

\author{
Timo Möykkynen • Paolo Capretti • Timo Pukkala
}

Received: 20 January 2014 / Accepted: 10 July 2014 / Published online: 30 July 2014

(C) INRA and Springer-Verlag France 2014

\begin{abstract}
- Context Fusarium circinatum is an invasive forest pathogen causing pitch canker in Europe. It attacks several pine species and Douglas firs. It has already invaded a few places in the Iberian Peninsula and Italy.

- Aims The aim of this study is to develop a model for simulating the spread of $F$. circinatum once it enters Europe via various entry points such as harbours, border stations and from nurseries containing tree seedlings.

- Methods The spread rate was modelled as a function of the spatial distribution of pine and Douglas firs, climatic suitability of different locations to F. circinatum, seedling transportation, insect-mediated transfer from tree to tree, and spread of airborne spores.

- Results The fungus is likely to spread to the pine forests of northern Spain (Galicia, Cantabria and Basque Country) and

\section{Handling Editor: Cécile Robin}

Contribution of the co-authors TM and TP developed the simulation model. TM conducted the simulations and participated in writing of the manuscript. PC provided biological information on the disease and participated in writing of the manuscript. TP programmed the model and participated in writing.
\end{abstract}

Key message Fusarium circinatum is an invasive pathogen causing pitch canker in pine and Douglas fir. This study developed a model for simulating the spread of $F$. circinatum in Europe. The simulations indicated that the fungus is likely to spread to the pine forests of northern Spain and southwest France.

T. Möykkynen $(\bowtie) \cdot$ T. Pukkala

University of Eastern Finland, PO Box 111, 80101 Joensuu, Finland

e-mail: timo.moykkynen@uef.fi

T. Pukkala

e-mail: timo.pukkala@uef.fi

P. Capretti

DISPAA Section of Plant Pathology and Entomology, University of Firenze, Piazzale delle Cascine, 28, 50144 Florence, Italy

e-mail: paolo.capretti@unifi.it southwest France (Aquitania). There will be some spread towards northern Portugal and southern Italy. Unless there are new arrivals to Central and North Europe, the fungus will not spread to the more northern parts of Europe. Due to the short dispersal distance of spores, $F$. circinatum cannot easily cross spatial discontinuities in the distribution of host species. - Conclusion F. circinatum is a serious potential invasive forest pathogen in Europe. New admittances of the spores from international trading should be controlled.

Keywords Invasive pathogen · Pine · Douglas fir . Spatio-temporal model $\cdot$ Spread model $\cdot$ Forest pathology

\section{Introduction}

Fusarium circinatum Nirenberg and O'Donnell is a potentially dangerous invasive pathogenic fungus found in Europe and elsewhere (Ganley et al. 2009). It causes a disease called pitch canker in trees. Climate change may affect the spread of the fungus. $F$. circinatum is present in pine and Douglas fir forests of all age classes in the USA, Japan, Korea and South Africa. In Europe, there are recent recordings of the fungus in Spain, Portugal, France and Italy (EFSA 2010). In Italy, for example, the fungus has been occasionally found in pine trees planted for ornamental purposes in a garden in the Province of Foggia (Carlucci et al. 2007). The planted trees had been transported from another locality, more than $200 \mathrm{~km}$ away from the area of detection.

F. circinatum spreads via contaminated seeds, seedlings, wood material, soil, wind, insect vectors and human activities. The spores infect wounds in trees caused by storms, hail, insects and pruning. The disease is most common in coastal areas because moisture is necessary for successful spore infection (Wikler et al. 2003; EPPO 2005). The infected trees grow slowly and suffer from branch and stem cankers and 
may die. Bark beetles commonly breed in infected branches and spread the pathogen when they fly to other trees (EPPO 2005). Furthermore, roots, shoots, female flowers, mature cones, seeds and seedlings may be affected (Wingfield et al. 2008). Based on host distribution and climatic conditions, potential outbreaks in Europe could occur in wide areas of central and northern Portugal, northern and eastern Spain, southern and coastal areas of France, coastal areas of Italy and parts of the coastal areas of Greece (Ganley et al. 2009; EFSA 2010). Prevention and control of the spread of F. circinatum is possible by limiting the transportation of seeds, plants, wood, soil and machinery from infected areas. Planting particular materials, such as certain pine species, which are less susceptible to the fungus, can also be applied as a prevention method (EPPO 2005).

F. circinatum is able to attack many European host species (EPPO 2005) and the European climate in many places is suitable for the development of pitch canker (Ganley et al. 2009; Watt et al. 2011). Recently, F. circinatum has been recommended to be designated as a quarantine pathogen in the member countries of the European and Mediterranean Plant Protection Organization (EPPO 2005).

Although the overall environmental requirements of F. circinatum are known, there are few numerical analyses about the likely rate of its spread in Europe and how the spread depends upon the number of new admittances and different control measures. These analyses would help to assess the need for specific control measures and evaluate the efficiency of alternative prevention and eradication strategies.

The aim of this study was to develop a stochastic spatiotemporal model for the spread of $F$. circinatum in Europe. The model simulates the spread of the pathogen from specified points of entry such as ports and infected nurseries. The developed model was run by using the known points of admittance in Portugal, Spain and Italy as the starting points of the spread (EFSA 2010). Repeated model runs that included a 1-year time step resulted in an infection probability map showing the risk of spread in different parts of Europe. In addition, long-term simulations were performed to see whether the fungus is likely to spread to central and northern Europe as a consequence of climate change.

\section{Spread modelling methodology}

\subsection{Model inputs}

The model and the software developed for the spread of F. circinatum is a cell-based simulator resembling a cellular automaton. The software, called PitchCanker, can be obtained from the authors.

The input grids (raster maps) of the simulation model are: (1) occurrence of host species, i.e. pines and Douglas firs and
(2) ecoclimatic index of $F$. circinatum. The raster map of host species was obtained by overlaying the species-specific maps developed by the European Forest Institute (Tröltzsch et al. 2009). The maps indicated the coverage of each species in a $1 \mathrm{~km}$ by $1 \mathrm{~km}$ grid. Overlaying all of the pine maps and the map of Douglas firs resulted in a raster of the total percentage coverage of all host species of $F$. circinatum (Fig. 1). The cell size, percentage of host species within a cell and the maximum number of mature host trees per hectare (500 in this study) were used to calculate the number of host trees in each cell. All host species were assumed to be equally susceptible to F. circinatum.

Another input of the simulation model is a list of points of potential F. circinatum arrival. In addition to the coordinates for each entry point, the following information is required: (1) first and last year of $F$. circinatum arrivals, and (2) number of F. circinatum arrivals per year. F. circinatum arrivals may be due to an infected seedling lot or other type of infected material.

\subsection{Developing the ecoclimatic index for pitch canker}

The climatic suitability map for pitch canker was developed with the dynamic simulation model CLIMEX. Suitability was described using the ecoclimatic index (EI), which defines the climatic suitability of a location for the species on a scale of 0 (unsuitable) to 100 (optimal) (Sutherst et al. 2007). EI is a combination of annual growth indices (population growth rate of the species as a function of soil moisture and temperature) and stress indices (cold, wet, hot, dry, cold-wet, cold-dry, hot-wet and hot-dry stress). CLIMEX also has a mechanism for defining the minimum temperature sum that is needed for population development. CLIMEX models are fitted to known distribution data by a manual iterative process (Ganley et al. 2009). Growth and stress parameters are adjusted and the model results are compared with the known geographical range of the species (Sutherst et al. 2007). As an alternative, parameter values affecting the species' response to temperature may also be determined in laboratory experiments (Desprez-Loustau et al. 2007). In this study, the values of growth and stress indices and the minimum temperature sum for pitch canker were obtained from Watt et al. (2011).

EI maps for pitch canker in Europe were produced for a period of previous climate data (1961-1990) and for the future 2071-2100 climate according to the climate scenario A1B. Scenario A1B describes medium-to-high greenhouse gas emissions and leads to mid-range estimates of global average temperature changes of around $3.4{ }^{\circ} \mathrm{C}$ by year 2100 (IPCC 2007). The CLIMEX climate change parameters for temperature and rainfall were determined separately for southern and northern Europe because they clearly differed from each other (Christensen et al. 2011) (Table 1). The EI maps obtained were then used as inputs for the spread model. The original range of EI $(0-100)$ was converted to range $0-1$. It was assumed that 
Fig. 1 Coverage of the host species Pinus spp. and

Pseudotsuga menziesii in Europe (dark tone implies high coverage) and the points of entry assumed in the study. The first three points of entry of $F$. circinatum (Gijon in 2003, Bilbao in 2003 and Brindisi in 2007) are the three southernmost dots. The other dots show the locations of the four additional points of entry, assumed in one 100-year simulation

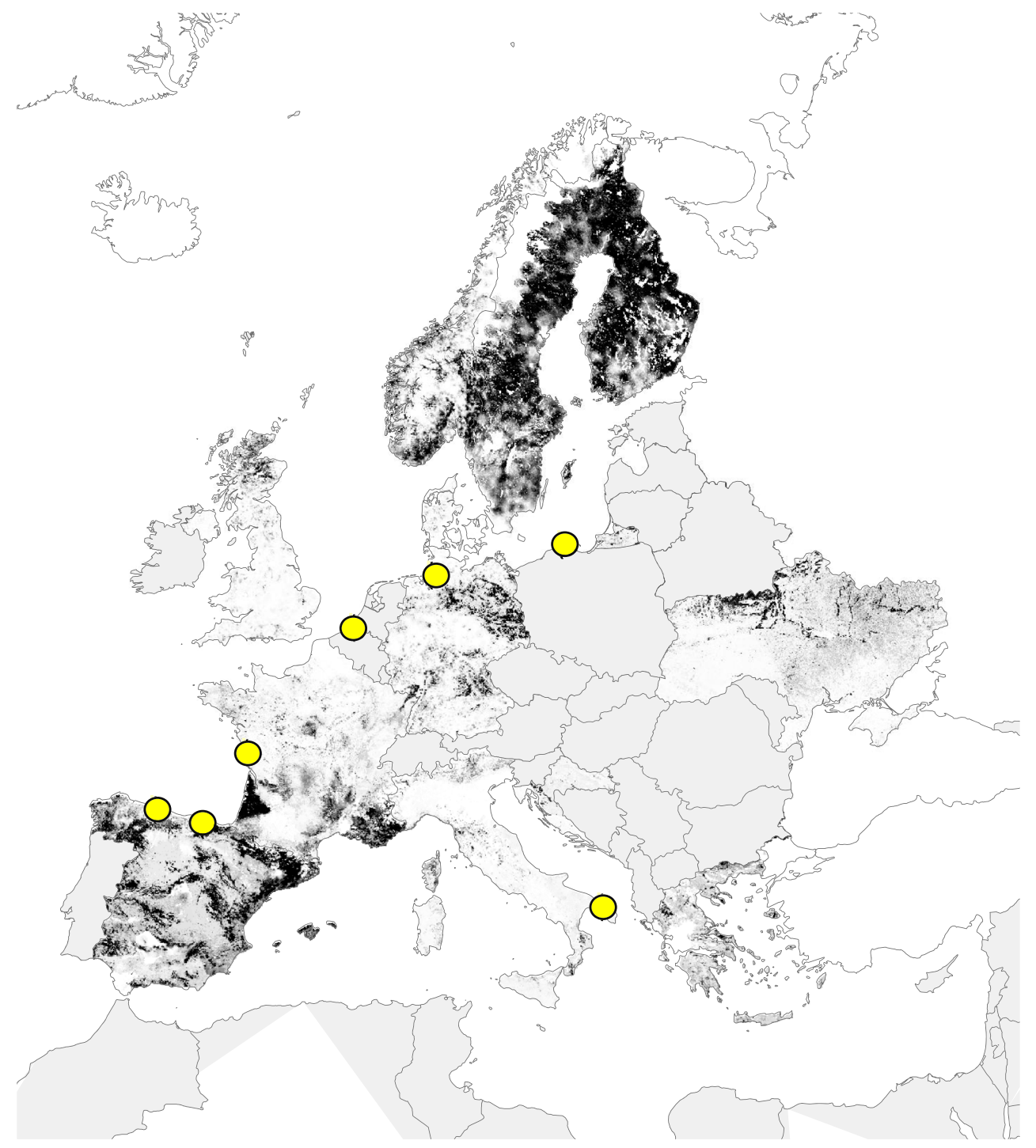

climate change does not affect the coverage or pitch canker host species.

\subsection{Simulation of spread from points of entry}

The model assumes that $F$. circinatum enters a new region via infected tree seedlings from nurseries, which are transported

Table 1 Predicted temperature and rainfall changes by year 2071-2100 in northern and southern Europe (IPCC 2007)

\begin{tabular}{lll}
\hline & $\begin{array}{l}\text { North of } \\
\text { latitude } 50\end{array}$ & $\begin{array}{l}\text { South of } \\
\text { latitude } 50\end{array}$ \\
\hline Winter temperature change, ${ }^{\circ} \mathrm{C}$ & +4.5 & +3 \\
Summer temperature change, ${ }^{\circ} \mathrm{C}$ & +3 & +4 \\
Winter rainfall change, $\%$ & +15 & 0 \\
Summer rainfall change, $\%$ & +10 & -20 \\
\hline
\end{tabular}

to forests of host species. Transporting distance and direction were drawn from uniform distributions (Fig. 2). The minimum transportation distance was set to zero and the maximum distance was set as a parameter (300 km used in this study). All directions were assumed to be equally probable. The destination cell obtained was accepted with the probability proportional to the coverage of the host species in the cell which basically means that pine and Douglas fir seedlings were transported to pine and Douglas fir forests. The destination cell was accepted if a uniform random number $\mathrm{U}[0,1]$ was smaller than the coverage of host species (percentage divided by 100). Otherwise, new destinations were generated until an accepted destination cell was found.

In the simulation, each infected seedling lot sends a certain number (100 in the simulations of this study) of spore dispatches to surrounding forests (Fig. 2). The direction of the dispersion is uniformly distributed between 0 and $360^{\circ}$ and its flight distance is drawn from negative exponential distribution 


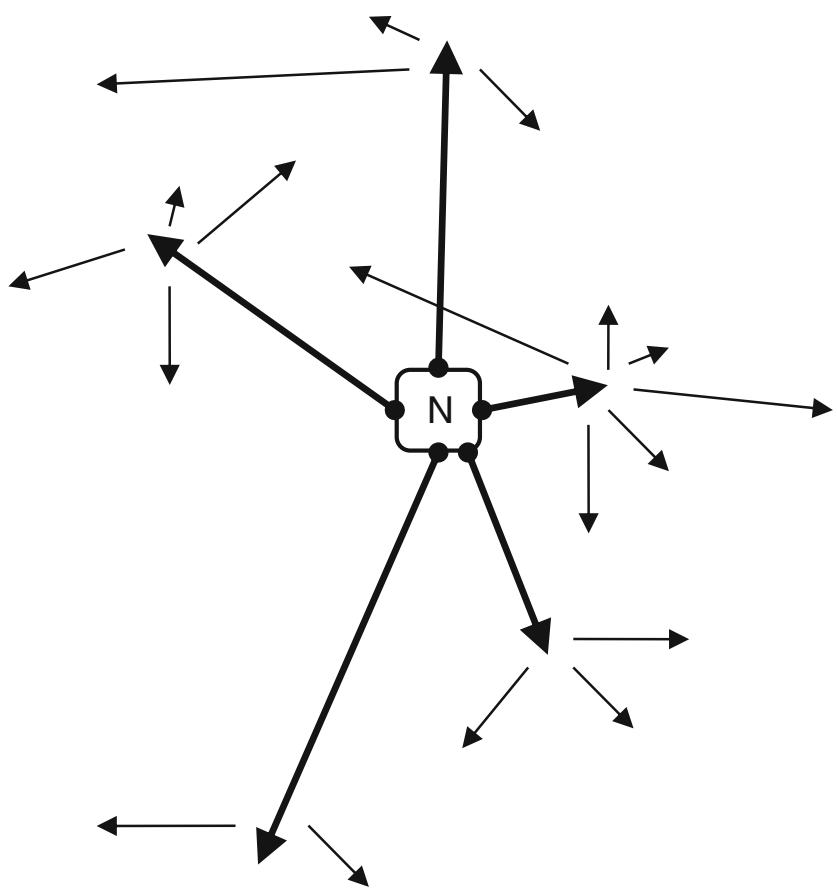

Fig. 2 The spread mechanism of $F$. circinatum from a nursery as simulated in the model. Thick lines represent seedling transport and thin lines represent spore dispatches

(Fig. 3) defined by the mean flight distance of spores (280 m; $1,300 \mathrm{~m}$ used as the maximum; see Wikler et al. 2003; Garbelotto et al. 2008). One host tree at the destination cell is infected with a probability that depends on the number of healthy host trees in the cell and the ecoclimatic index of F. circinatum in the cell in that year:

$p_{\text {infection }}=\left[N_{\text {healthy }} / N_{\max }\right] \times \mathrm{EI}$

where $p_{\text {infection }}$ is the probability that one tree is infected, $N_{\text {healthy }}$ is the number of healthy trees in the cell, $N_{\max }$ is the maximum possible number of host species in a cell (500 trees/

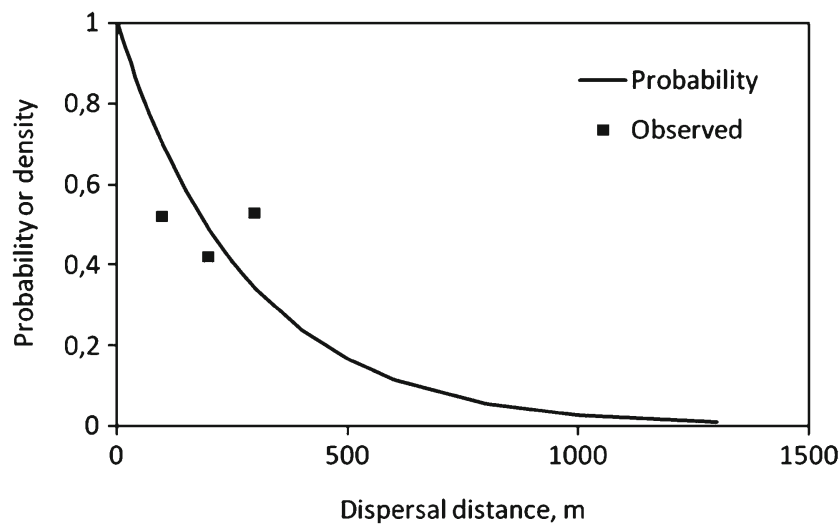

Fig. 3 Assumed distribution of $F$. circinatum spore dispersal distances and the effect of distance on the relative spore density around an infected cell. Observations were obtained from Garbelotto et al. (2008) ha times cell size in hectares), and EI is the ecoclimatic index $(0-1)$ of the cell. The ratio $N_{\text {healthy }} / N_{\max }$ is the probability of hitting a healthy host tree and EI is a measure of climatic suitability of the cell for $F$. circinatum infection. The EI of a particular simulation year was linearly interpolated from two EI rasters (current climate and that of 2100). Therefore, the effect of climate change on the vigour of $F$. circinatum is taken into account. Infection was assumed to occur if a uniform random number $\mathrm{U}[0,1]$ was smaller than $p_{\text {infection. }}$. The infected tree will remain infected and potentially be able to spread infection for a certain number of years ( 5 years in the simulations of this study). It will send infected insects and spores to surrounding forests as long as it remains infected (see next section).

\subsection{Simulating the spread of $F$. circinatum from infected cells}

The model included two potential spread mechanisms from infected cells: by insects and by wind dispersal of spores (Wingfield et al. 2008) (Fig. 4). In the model, each infected tree contain a certain number of insects capable of carrying the disease to healthy trees. The flight direction of the insect is drawn from a uniform distribution $\left(0-360^{\circ}\right)$ and its flight distance is drawn from a negative exponential distribution defined by the mean flight distance of insects $(1,000 \mathrm{~m}$; 4,500 $\mathrm{m}$ used as the maximum; see e.g. Costa et al. 2013; Withrow et al. 2013). The insect infests a healthy pine with a probability calculated with Eq. 1. Infection occurs if a uniform random number $\mathrm{U}[0,1]$ is smaller than the probability. If infection is unsuccessful, the insect has more tries to find a healthy host tree. Repeating the process of finding a random destination and generating a random infection mimics the natural active behaviour of the insect when it seeks a suitable

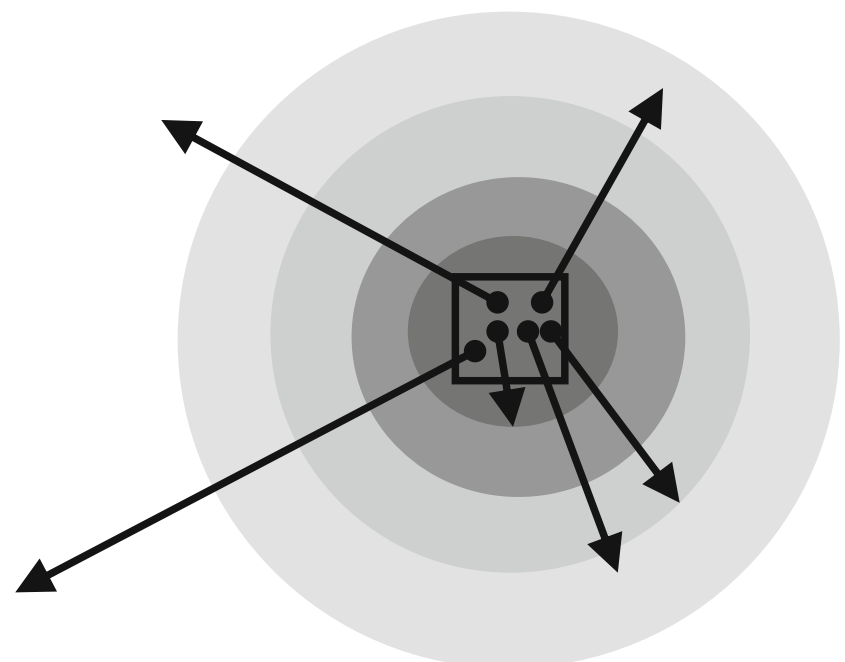

Fig. 4 The spread mechanisms of $F$. circinatum from an infected cell. Spore dispersal is simulated by calculating a spore density field around an infected cell (grey tone represents spore density). Spread in insect vectors is simulated by generating flight destinations on infected insects (arrows) 
host tree. In the simulations of this study, it was assumed that each tree capable of spreading disease has one infected insect leaving from it, and an insect has 10 tries to find a healthy host tree.

The other spread mechanism from infected cells is by airborne spores. Since it is computationally too demanding to simulate the flight of individual spores, the simulation was accomplished by calculating a relative spore density field around each infected cell (Fig. 4). The radius of spore dispersal zone around the midpoint of an infected cell was assumed to be $1,300 \mathrm{~m}$ (Fig. 3). In the middle of the donor cell the relative spore density was:

Donor spore density $=N_{\text {spreading }} / N_{\max }$

where $N_{\text {spreading }}$ is the number of trees disseminating spores in the donor cell and $N_{\max }$ is the maximum possible number of host trees in a cell (500 trees/ha times cell size, i.e. 100 ha). The spore density was assumed to decrease according to negative exponential function (Fig. 3) as defined by the mean flight distance of a spore:

Recipient spore density $=$ donor spore density

$$
\times \exp \left(-\operatorname{distance} / F_{\text {mean }}\right)
$$

where distance is the distance between donor and recipient cell and $F_{\text {mean }}$ is the mean flight distance of spores $(280 \mathrm{~m})$ (Garbelotto et al. 2008). The number of new infections in a cell within the influence zone of the donor cell was obtained from:

$N_{\text {new infections }}=N_{\text {healthy }} \times \mathrm{EI} \times$ recipient spore density

If the number is, for instance, 5.4, five healthy trees are infected and a sixth tree is infected with a probability of 0.4 . Each infected trees remains potentially capablse of spreading disease for a specified number of years (five in this study), after which its state is 'dead'.

\subsection{Simulations}

In summary, the baseline parameters used in the simulations of this study were as follows (in parentheses it is expressed if the parameter is human controllable, based on literature or assumption):

- Number of infected seedling lots per year and entry point $=100$ (controllable)

- Maximum distance of seedling transport from a nursery= $300 \mathrm{~km}$ (controllable)
- Number of spore dispatches per infected seedling lot $=100$ (assumption/controllable)

- Mean flight distance of spores $=280 \mathrm{~m}$ (literature)

- Maximum flight distance of spores=1,300 m (literature)

- Maximum number of host trees per hectare=500 (controllable)

- Number of infected insects per tree capable of spreading disease $=1$ (assumption)

- Number of tries an insect has to find a host tree $=10$ (assumption)

- Mean flight distance of insects $=1,000 \mathrm{~m}$ (literature)

- Maximum flight distance of insects=4,500 m (literature)

- Number of years an infected tree is remains infected and with the potential to spread disease $=5$ (assumption)

Three entry points were used (Fig. 1, Table 2). They are nurseries where infected seedlings were transported to surrounding forests. However, they could also be ports through which infested material is transported to Europe. In the case of nurseries, the number of arrivals is the number of infected seedling lots.

The simulations were completed for a 20 -year period. The baseline simulation (using the above parameter values) was repeated 10 times, resulting in a map of the probability of infection. The simulator also output a raster map of infection year (first infection in each cell), which made it possible to visualise the temporal progress of the spread. Another output raster was the number of trees in each cell that were infected during the simulation period. Also, the number of trees capable of spreading disease at the end of the simulation was calculated, making it possible to display the status or "front" of the spread in a particular year.

In addition to the baseline simulations, sensitivity analyses were conducted by changing the value of one parameter at a time. All simulations were repeated 10 times, to reduce the effect of stochastic elements of the model. To examine a particular case of sensitivity, the effects of increased seedling transportation distance and increased amount of insect vectors were visualised with maps. A long-term simulation of 100 years was also performed. Since the CLIMEX calculations indicated that the area suitable for pitch canker will move northward as a consequence of climate change, long-term simulations would reveal whether $F$. circinatum infestation would follow climate-induced changes in the environment.

Table 2 Points of entry of $F$. circinatum used in the simulations (EFSA 2010) in this study

\begin{tabular}{llll}
\hline Location & $\begin{array}{l}\text { Number } \\
\text { of arrivals }\end{array}$ & $\begin{array}{l}\text { First year } \\
\text { of arrivals }\end{array}$ & $\begin{array}{l}\text { Last year } \\
\text { of arrivals }\end{array}$ \\
\hline Bilbao, Spain & 100 & 1 & 20 \\
Gijon, Spain & 100 & 1 & 20 \\
Brindisi, Italy & 100 & 4 & 20 \\
\hline
\end{tabular}


This simulation was performed with seven entry points: (1) three existing entry points in south Europe (three southernmost dots in Fig. 1) and (2) four additional points in other parts of Europe (all other dots shown in Fig. 1). Arrivals from the four additional points were started from south to north, in years $10,20,30$ and 40, respectively, and lasted for 10 years each. The arrivals from the three southernmost points started in the first year and lasted for 10 years. The number of arrivals per entry point and per year was 100 .

\section{Results}

The maps of ecoclimatic index produced with the CLIMEX model showed that the suitable area for development of pitch canker increased with climate change and moved northwards (Fig. 5). For example, Portugal and South Italy became less vulnerable whereas the susceptibility of coastal areas of northern Italy increased, and Great Britain, which currently has an unsuitable climate for pitch canker, became vulnerable.

According to 10 simulations with the baseline parameters given above, the pitch canker was predicted to spread to northern Spain and Portugal, and South-West France by year 2034 (Figs. 6 and 7). The fungus was predicted to heavily infect the Pinus pinaster forests of Aquitania in South-West France. In Spain, the most heavily infected areas were Galicia, Cantabria and Basque Country. There was much less spread from the point of entry in southern Italy.

Sensitivity analyses revealed that the percentage of infected pine area was sensitive to the number of arrivals (infected seedling lots from nurseries), up to 100 arrivals (Fig. 8a). It

Fig. 5 Ecoclimatic index (EI) of pitch canker in current climate (top) in the climate of year 2100 according to climate scenario A1B (bottom). Black suitable $(\mathrm{EI}=1)$, white unsuitable $(\mathrm{EI}=0)$

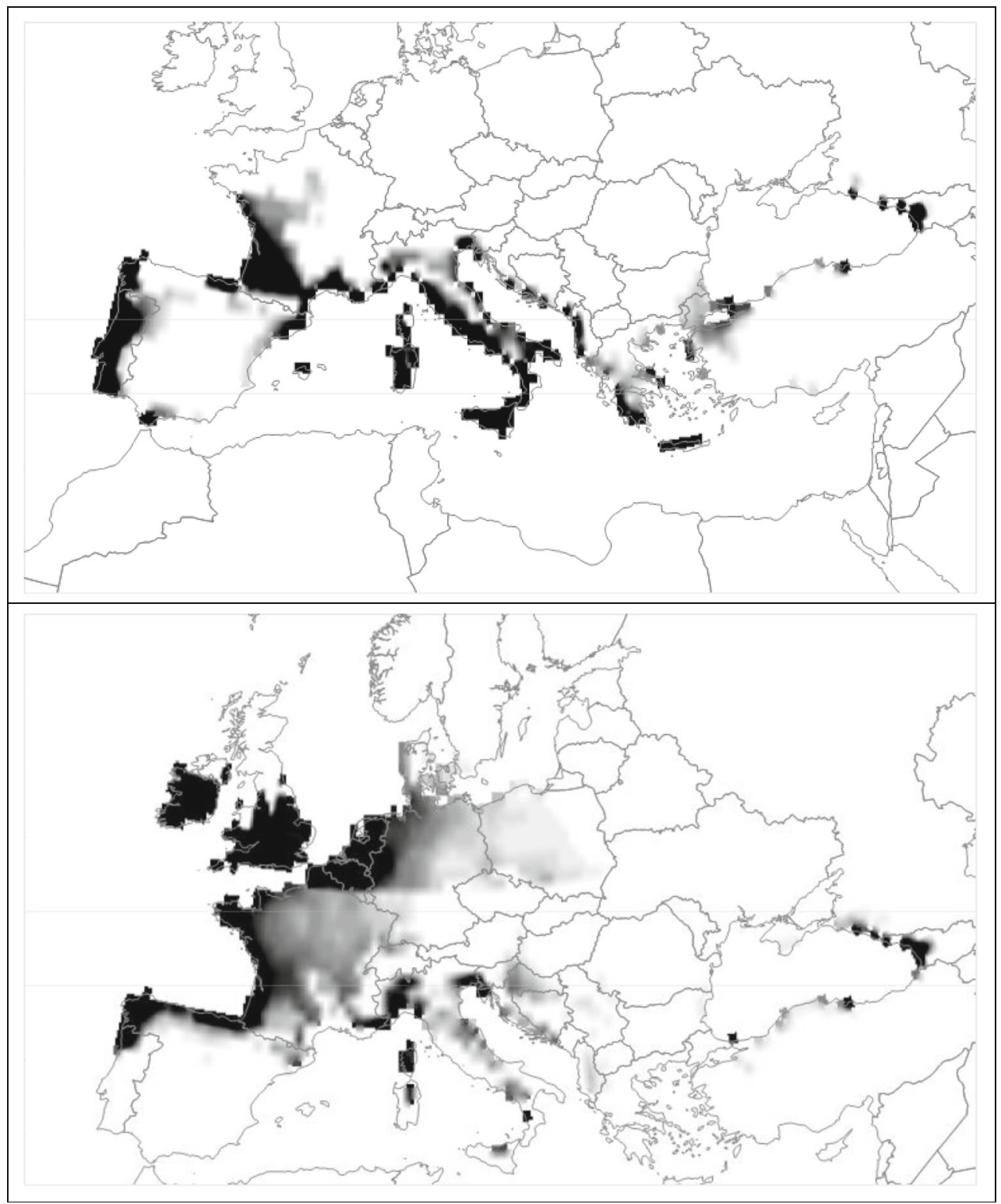


Fig. 6 Probability of spread of pitch canker by year 2025 based on 10 repeated simulations from three points of entry (Gijon, Bilbao and Brindisi). Red high probability (100\%); yellow medium probability (40-60\%); green low probability (10-20\%)
Fig. 7 To $p$ Predicted spread of pitch canker during 2005-2025 in one simulation (red infested in 2005-2010, green infested in 2020-2025). Bottom Number of spreading trees in 2025 (dark red $>100$ trees/ha, light red $<2$ trees/ ha)
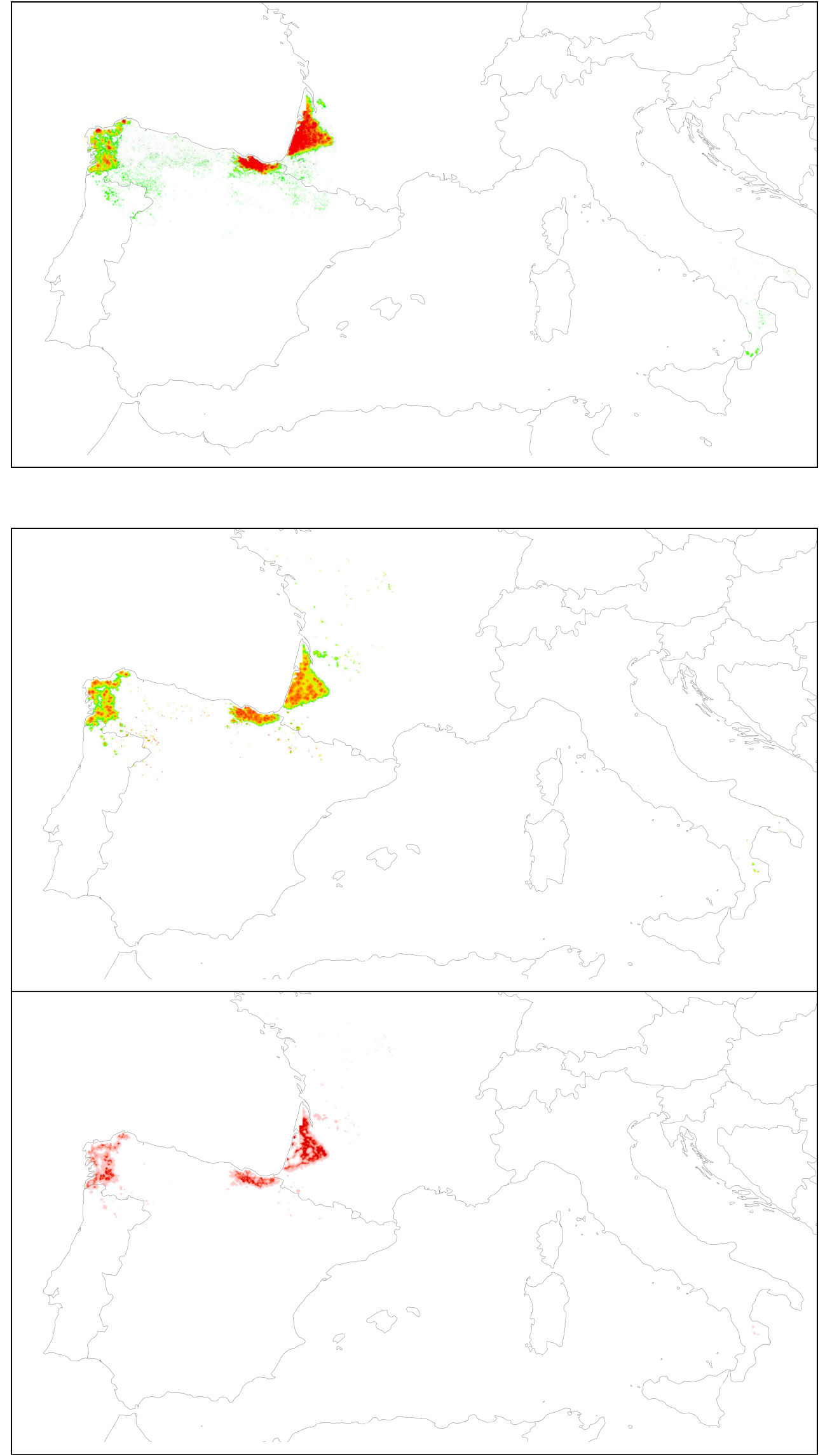
Fig. 8 Results of the sensitivity analyses. Solid line represents the baseline simulation with default parameter values
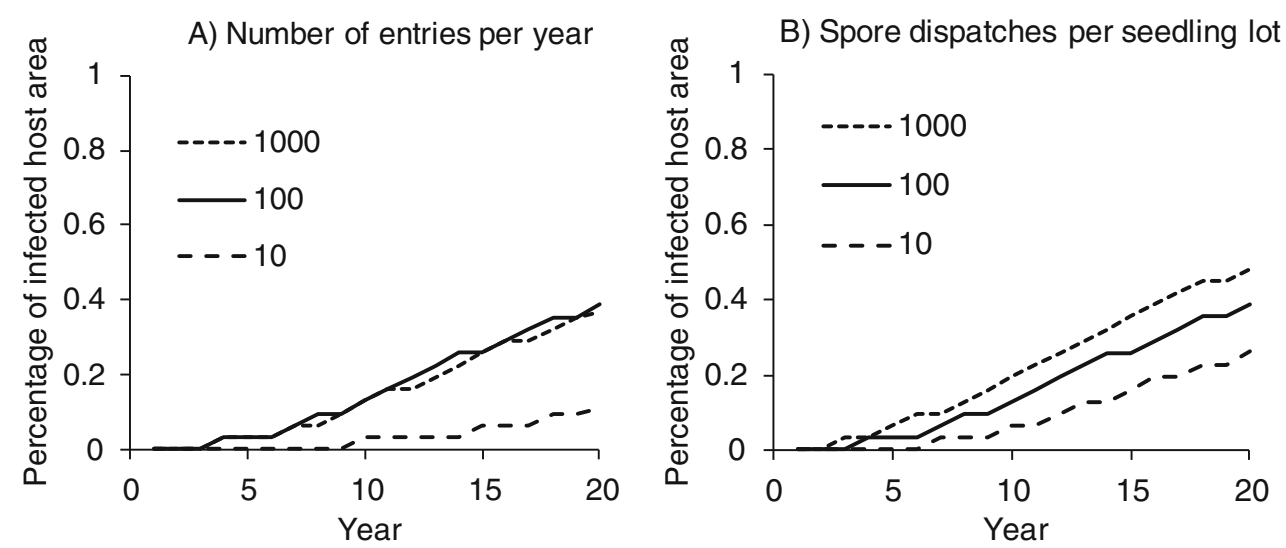

C) Number of insects per infected tree
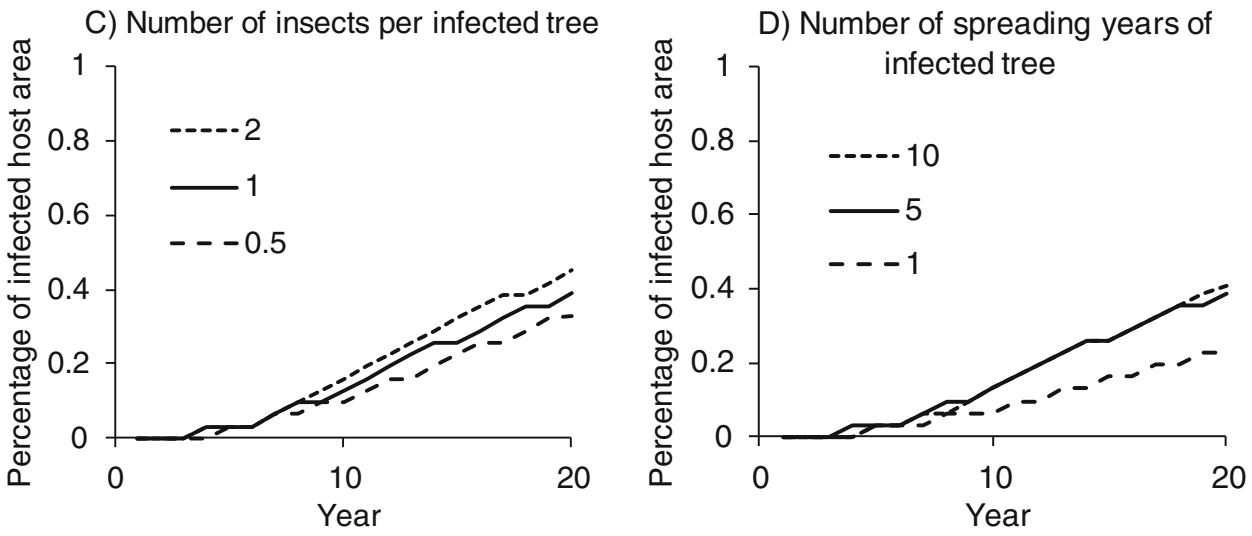

E) Spore dispersal distance, $m$

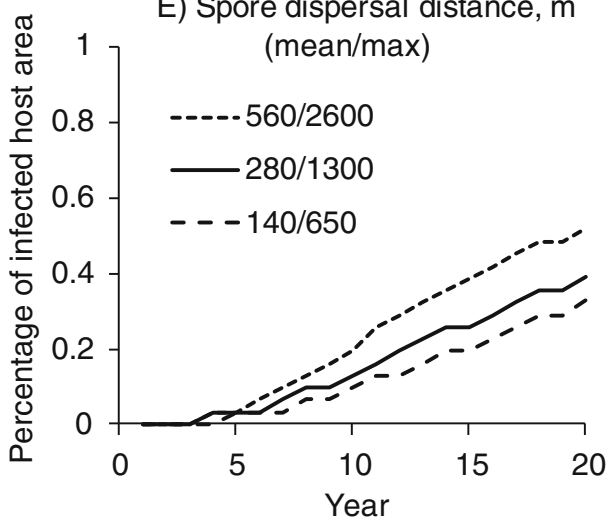

was also sensitive to the number of infective spores that diffused from infected seedling lots (Fig. 8b). The percentage area of infected pine and Douglas fir forests was not particularly sensitive to the number of spreading insects per infected tree (Fig. 8c). The model was sensitive to the number of years that an infected tree diffuses spores, up to 5 years (Fig. 8d) and to spore dispersal distance (Fig. 8e). However, the model was not sensitive to the flight distance of insect vectors (Fig. 8e), most probably because the assumed number of insects was low (one insect per infected tree and year).

The effect of the distribution of the flight distance of insect vectors was also analysed (Fig. 9). Exponential distribution was compared to a two-parameter Weibull distribution, which was used with two different values of the shape parameter (c). Each distribution was used with and without cutting the distribution at $4,500 \mathrm{~m}$. The analysis indicated that the model is not particularly sensitive to the distribution from which candidate flight distances are drawn. The accepted flights are not distributed in the way as the candidate distances, which may explain the small effect of the used distribution function. Truncation of the distribution slightly decreased the spread rate, which can be explained by the fact that it takes a longer time to reach a distant location when the maximum flight distance is shorter.

The output maps of the baseline simulations (Figs. 6 and 7) suggested that pitch canker does not spread to all European 

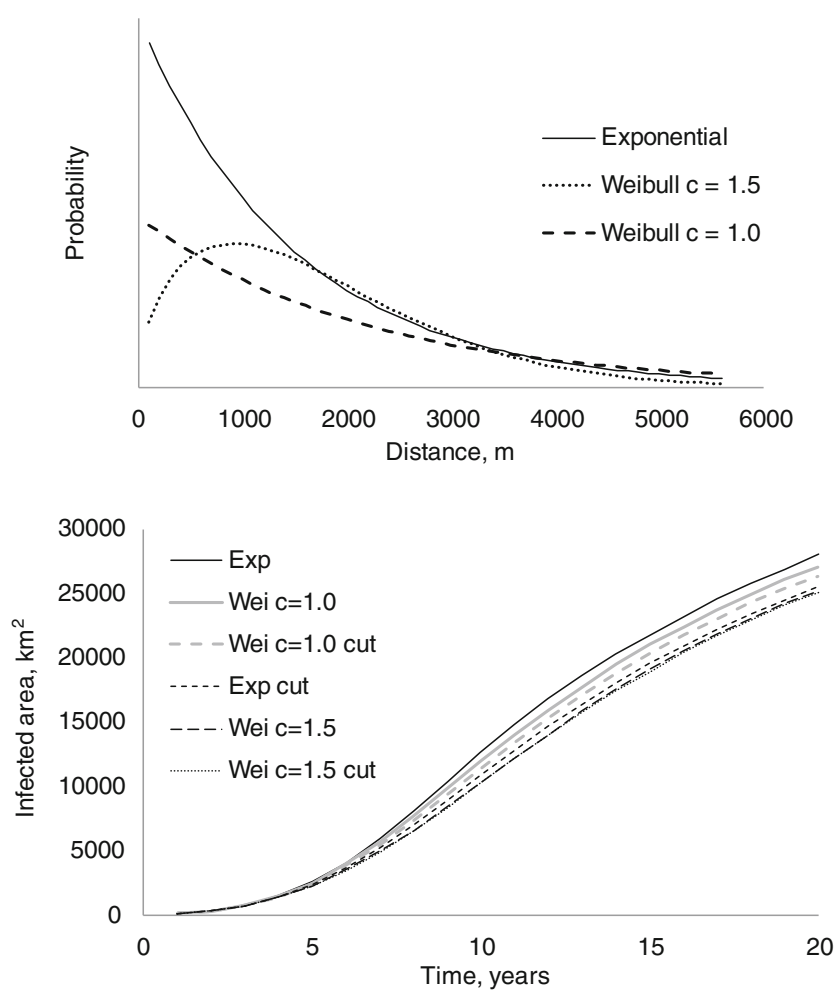

Fig. 9 Effect of distribution of the flight distance of insect vectors (top) on the spread of pitch canker in a 20 -year simulation (bottom). Default values were used for parameters other than flight distance. Each distribution was used without and with truncation at 4,500 $\mathrm{m}(\mathrm{cut})$. The twoparameter Weibull distribution was used with two different values of the shape parameter $(c)$. The location parameter $(b)$ was calculated from $c$ with a mean flight distance of $1,500 \mathrm{~m}$

pine forests that are climatically suitable. The rather restricted spread may be related to the short transportation distances of seedlings, short flight distance of insects, and short dispersal distance of spores. The simulations shown in Fig. 10 visualise the effects of increasing transportation distance and increased dispersal by insects. Although they are outputs from single runs of a stochastic simulator, comparisons with Fig. 7 (top) suggested that the regions where $F$. circinatum will spread are mainly dictated by the locations of points of entry, and the transportation distance of seedlings. Increasing number and increasing flight distance of insects enhanced the spread within the regions into which $F$. circinatum had been transported in infected materials.

The 100-year simulation (Fig. 11) was performed with the assumption that there will be new arrivals in France, Benelux countries, Germany and Poland, each lasting for 10 years. The results show that there will be additional infestations in France, Benelux countries and Germany, and some infestation also in Poland. There was no spread to Great Britain, although this country was predicted to become climatically suitable for pitch canker (Fig. 5). It was apparent that the disease began to shrink if dead trees were not replaced by new trees that were suitable hosts for F. circinatum (Fig. 11, bottom). At the end of the simulation, the highest densities of trees capable of spreading disease were in the Pyrenees, central France and northern Germany.

\section{Discussion}

The model developed in this study for simulating the spread of $F$. circinatum reproduced the various sub-processes of the spread in a straightforward mechanistic way. Since pitch canker is a new disease in Europe, it is impossible to verify the model on the basis of empirical data. However, spread models developed earlier for pitch canker (Ganley et al. 2009; Watt et al. 2011) and pinewood nematode (Pukkala et al. 2014) have predicted spread rates that are in line with the observed realised spread. In addition, it should be noted that the spread is largely a random process, and the realised spread represents just one example of a stochastic phenomenon. Therefore, small discrepancies between observed spread and a single model run do not prove that the model is incorrect; the model is wrong if it never produces simulations that agree with the observed spread. The purpose of the model is to assess risks (probabilities), not to provide exact predictions of spread.

The assumed spread mechanisms of $F$. circinatum were via seedling transport (although they could be other objects), insect-mediated spread from infected trees, and spread by airborne spores from infected trees. The probability of infection depended on the ecoclimatic index (EI) of the recipient cell and the number of healthy host trees in the destination cells. The ability of a donor cell to infect other cells depended on the number of infected trees within the donor cell. The states of a tree were designated as healthy, infected, able to spread and dead. The states of the cell were the same (infected when at least one tree is infected, dead when all trees are dead) but cell states were never used in the simulation. The cell-level variables that needed to be kept in the memory of the simulator were (in addition to the EI):

1. Total number of host trees

2. Number of new infections in the current simulation year

3. Number of trees infected 1 year ago

4. Number of trees infected 2 years ago

5. ....

$n$. Number of trees infected $n-2$ years ago

Trees in categories 3- $n$ were able to spread disease, and $n$ depended on the number of years that an infected tree remained infected and capable of spreading disease ( 5 years in this study, implying that $n=7$ ). At the end of each year, trees in the last category were 'discarded' since they were no longer required in simulation. The status of categories $2-n-1$ was 


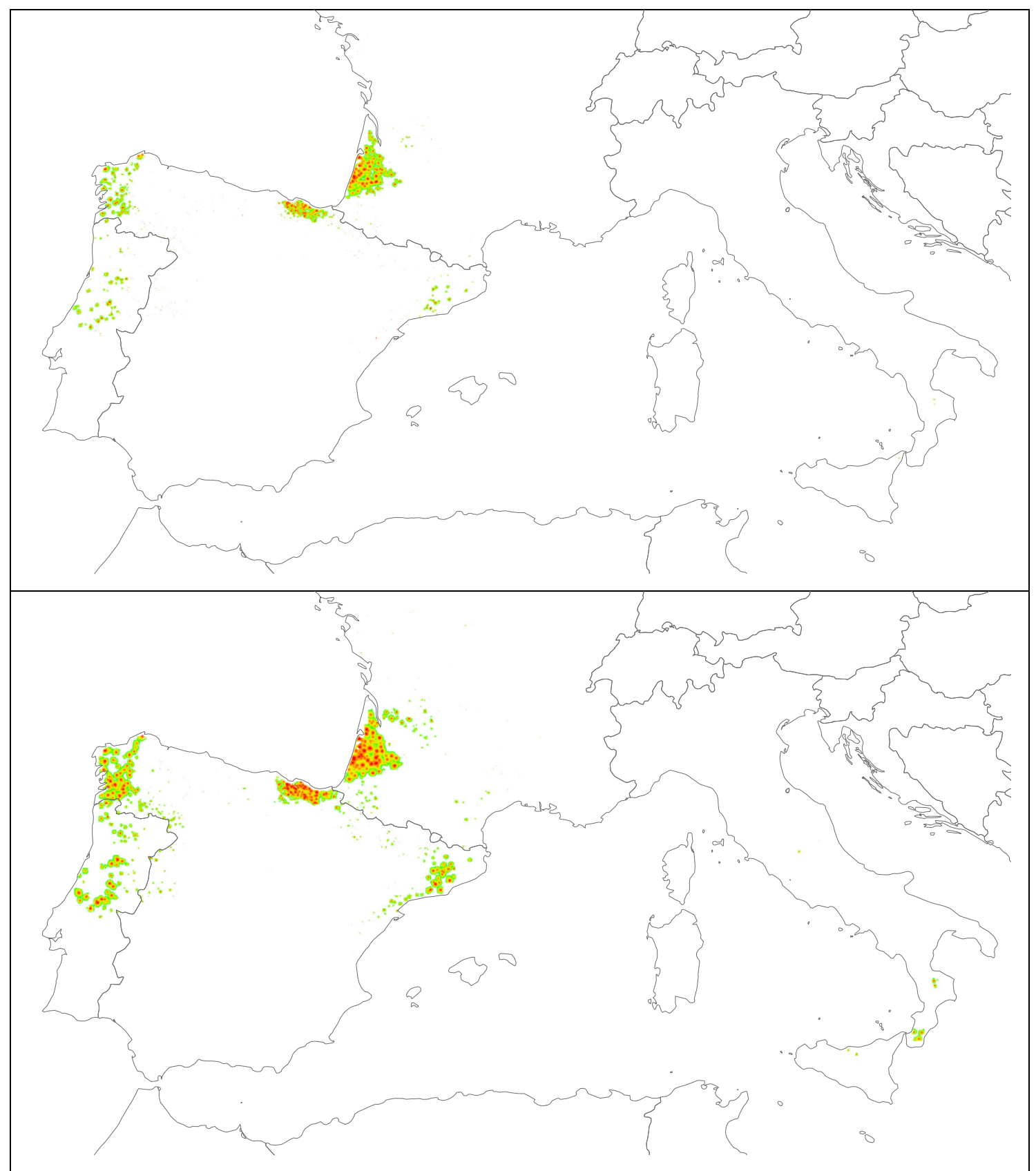

Fig. 10 Infection year in two 20-year simulations (red within 5 years; green years 15-20). Top maximum transportation distance of seedlings is $500 \mathrm{~km}$ (instead of $300 \mathrm{~km}$ in the baseline simulations). Bottom maximum transportation distance is $500 \mathrm{~km}$, insect flight distance is doubled, and there are 10 times more insect vectors as compared to the baseline simulation

shifted one step forward. The model may be called a mechanistic model since the simulation tries to mimic the same processes that cause the spread of the disease. The model has similarities with a cellular automaton (CA), but it is more fine-grained than a typical CA.

The area of suitable climate for the development of pitch canker in Europe was predicted to shift from coastal areas of southern Europe northwards by year 2100. This was caused by decreasing summer precipitation and increasing summer and winter temperatures in southern Europe (south of latitude
50). In northern Europe (north of latitude 50), increasing summer and winter precipitation and increasing summer and winter temperatures (Christensen et al. 2011) make the

Fig. 11 100-year simulation from seven points of entry of F. circinatum in Europe (dots in Fig. 1). Top infection year (red within 20 years; yellow in 40-60 years; green years 75-100); middle total number of infected trees during 100-year simulation (red $>100$ trees/ha; yellow $<2$ trees/ha); Bottom number of trees capable of spreading disease at the end of a 100year simulation (dark red $>100$ trees/ha; light red $<2$ trees/ha) 


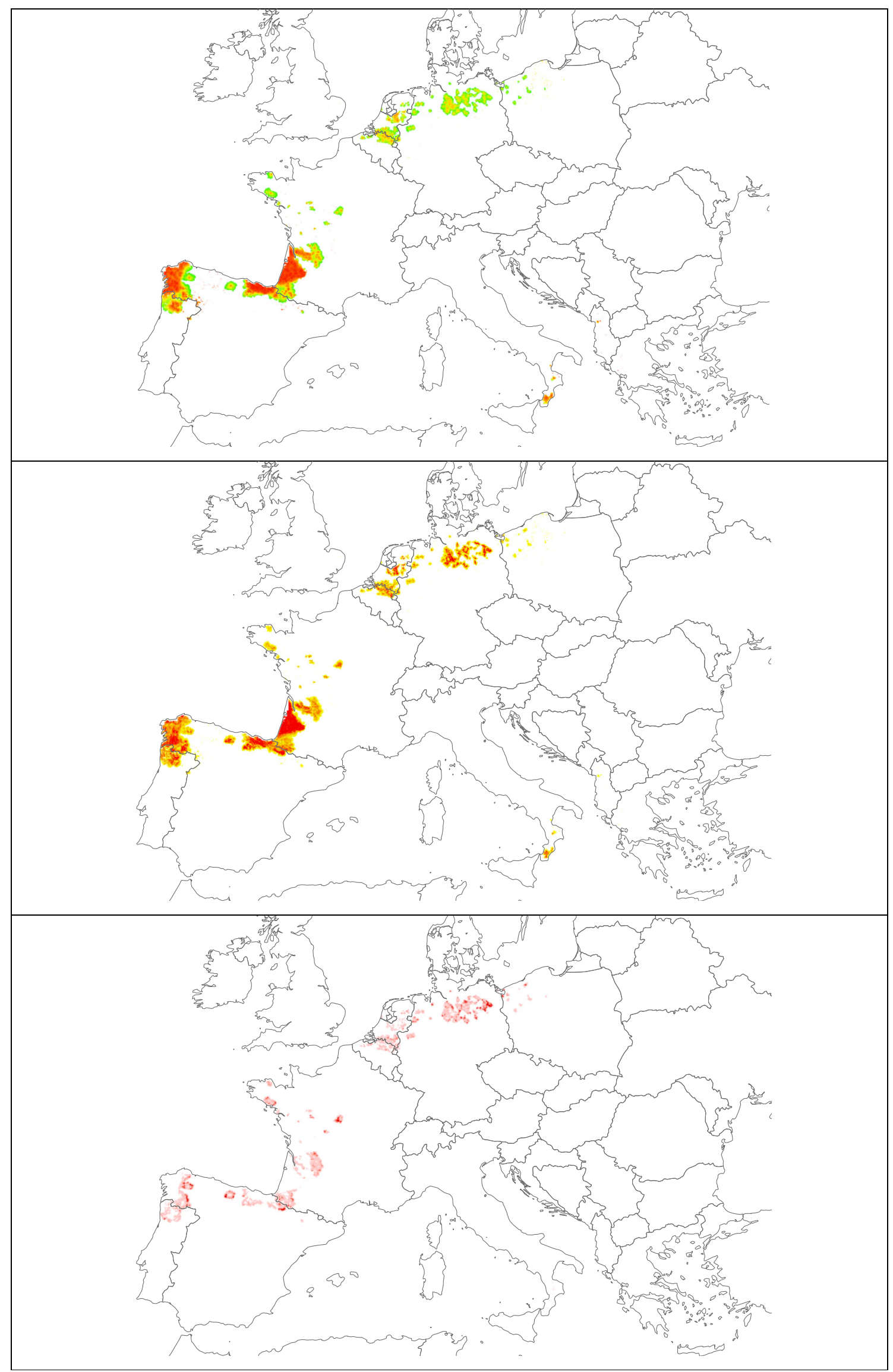


climatic conditions more favourable for $F$. circinatum. However, the simulations indicated that pitch canker is not likely to spread to Central and North Europe unless new points of entry are created during those climatic periods when the region is suitable for the development of the disease. Lack of spread is partly due to the short flight distance of spores, which makes it difficult for the fungus to cross spatial gaps in the distribution of suitable host species. Spread is also limited by the fact that inner parts of the continent are climatically unsuitable for F. circinatum.

The overall spread rate of $F$. circinatum is largely defined by the place and number of points of entry of the fungus, transportation of infected materials and the flight distances of spores and insects. The first two factors can be controlled by human decision making. A few measurements were available for estimating the distribution of the flight distance of spores and insects, but the number of insect vectors was only an educated guess. Although the model is not sensitive to small changes in the number and flight distance of insects, it is important to know the typical range of the number of insect vectors, as well as their flight distances.

Generally, the flight length of bark beetles varies a great deal. According to Safranyik and Carroll (2006), Dendroctonus ponderosae has three principal modes of dispersal: (1) attacking the nearest suitable host tree (only a few metres), (2) attacking after a period of flight exercise (a few hundred metres) and (3) becoming caught in upward drafts and being transported by wind (tens or hundreds of kilometres). According to Costa et al. (2013), $50 \%$ of Ips grandicollis, a bark beetle of Pinus resinosa, flew less than $130 \mathrm{~m}, 50 \%$ of Dendroctonus frontalis flew less than $690 \mathrm{~m}$ and some individuals of Dendroctonus valens flew more than $1,000 \mathrm{~m}$ in field studies. According to Withrow et al. (2013), $68 \%$ of Dendroctonus pseudotsugae bark beetles flew $1,000 \mathrm{~m}$ in Colorado and 2,500 $\mathrm{m}$ in Wyoming. According to Wermelinger (2004), Ips typographus, the spruce bark beetle, flew more than $500 \mathrm{~m}$ and Botterweg (2009) found it was capable of flying more than $8,000 \mathrm{~m}$ outside forest areas. According to Robertson et al. (2009), Dendroctonus ponderosae dispersal distance was at most 2,000 $\mathrm{m}$ in Pinus contorta areas in Canada. Flight-mill tests in the laboratory (Byers 2000) have revealed that $50 \%$ of Ips sexdentatus have flown more than $20 \mathrm{~km}$ and I. typographus could fly up to $46 \mathrm{~km}$. D. pseudotsugae have been found to fly up to $60 \mathrm{~km}$ and Dendroctonus frontalis up to $43 \mathrm{~km}$. However, flight-mill tests may overestimate the maximum flight length of bark beetles because in nature the insects usually stop flying when they find a suitable host tree. According to Nilssen (1984) Dryocoetes autographus, Hylastes cunicularius, Hylastes brunneus and Hylobius abietis were found in trap logs as far as $171 \mathrm{~km}$ from the nearest forests in northern Finland and it was concluded that they were dispersed by wind. We used moderate flight lengths of insects with a mean distance of
$1,000 \mathrm{~m}$ and a maximum of $4,500 \mathrm{~m}$ in the baseline simulations in this study.

The model was rather insensitive to the assumed shape, mean and maximum of the distribution of candidate flight distances of insects. Sensitivity analyses also revealed that the model was not very sensitive to the dispersal distance of spores. According to Garbelotto et al. (2008), the relative amount of spore deposition of $F$. circinatum in northern California was around 0.5 at $100-300 \mathrm{~m}$ from the source. We used this information to estimate the spore density gradient used in this study (Fig. 3).

The most important non-controllable parameter determining the infection of trees by F. circinatum appears to be the ecoclimatic index and its temporal development. The pitch canker was predicted to spread from the three currently known points of entry to relatively wide areas containing Pinus forests and having a suitable climate. However, compared to some other pathogens such as Hymenoscyphus pseudoalbidus (Timmermann et al. 2011), which may spread all over Europe and is impossible to control, the spread of F. circinatum remains more limited, mainly due to the short dispersal distances of the spores. If there were more points of entry in the future, large areas of pine forests in coastal areas of southern and Central Europe could be affected. On the other hand, the spread rate is not very fast. Since the flight distance of insect vectors is also fairly short, eradication of the disease seems to be possible by isolating the infested forests, preventing new points of admission, and avoiding the transport of any infected materials. Therefore, it seems possible to stop the spread by utilising and enlarging the physical gaps and discontinuities in the occurrence of host species.

Acknowledgments This study was performed with funding from the EU-funded project ISEFOR (Increasing Sustainability of European Forests: modelling for security against invasive pests and pathogens under climate change).

\section{References}

Botterweg PF (2009) Dispersal and flight behavior of the spruce bark beetle Ips typographus in relation to sex, size and fat content. J Appl Entomol 94:466-480

Byers JA (2000) Wind-aided dispersal of simulated bark beetles flying through forests. Ecol Model 125:231-243

Carlucci A, Colatruglio L, Frisullo S (2007) First report of pitch canker caused by Fusarium circinatum on Pinus halepensis and P. pinea in Apulia (Southern Italy). Plant Dis 91:1683

Christensen OB, Goodess CM, Harris I, Watkiss P (2011) European and global climate change projections: discussion of climate change model outputs, scenarios and uncertainty in the EC RTD Climate Cost project. In: Watkiss $\mathrm{P}$ (ed) The climate cost project, Final report. Volume 1: Europe. Stockholm Environment Institute, Sweden, ISBN 978-91-86125-35-6

Costa A, Min A, Boone CK, Kendrick AP, Murphy RJ, Sharpee WC, Raffa KF, Reeve JD (2013) Dispersal and edge behavior of bark 
beetles and predators inhabiting red pine plantations. Agric For Entomol 15:1-11. doi:10.1111/j.1461-9563.2012.00585.x

Desprez-Loustau M-L, Robin C, Reynaud R, Deque M, Badeau V, Piou D, Husson C, Marcais B (2007) Simulating the effects of a climatechange scenario on the geographical range and activity of forestpathogenic fungi. Can J Plant Pathol 29:101-120

EFSA Panel on Plant Health (PLH) (2010) Risk assessment of Gibberella circinata for the EU territory and identification and evaluation of risk management options. EFSA J 8:1620, 93 pp

EPPO (2005) Data sheets on quarantine pests. Gibberella circinata. EPPO Bull 35:383-386

Ganley RJ, Watt MS, Manning L, Iturritxa E (2009) A global climatic risk assessment of pitch canker disease. Can J For Res 39:2246-2256

Garbelotto M, Smith T, Schweigkofler W (2008) Variation in rates of spore deposition of Fusarium circinatum, the causal agent of Pine Pitch Canker, over a 12-month period at two locations in northern California. Phytopathology 98:137-143

IPCC (2007) Summary for policymakers. In: Solomon SD, Qin M, Manning Z, Chen M, Marquis M, Averyt KB, Tignor M, Miller HL (eds) Climate change 2007: the physical science basis. Contribution of working group I to the fourth assessment report of the Intergovernmental Panel on Climate Change. Cambridge University Press, Cambridge

Nilssen AC (1984) Long-range aerial dispersal of bark beetles and bark weevils (Coleoptera, Scolytidae and Curculionidae) in northern Finland. Ann Entomol Fenn 50:37-42

Pukkala T, Möykkynen T, Robinet C (2014) Comparison of the potential spread of pinewood nematode (Bursaphelenchus xylophilus) in Finland and Iberia simulated with a cellular automaton model. For Pathol. doi:10.1111/efp.12105

Robertson C, Nelson TA, Jelinski DE, Wulder MA, Boots B (2009) Spatial-temporal analysis of species range expansion: the case of the mountain pine beetle, Dendroctonus ponderosae. J Biogeogr 36: 1446-1458
Safranyik L, Carroll A (2006) The biology and epidemiology of the mountain pine beetle in lodgepole pine forests. In: Safranyik L, Wilson B (eds) The mountain pine beetle, a synthesis of biology, management and impacts on lodgepole pine. Natural Resources Canada, Canadian Forest Service, Pacific Forestry Service, Victoria, pp 3-66

Sutherst RW, Maywald GF, Kriticos DJ (2007) CLIMEX version 3: user's guide. Hearne Scientific software Pty Ltd., Melbourne, http://www.hearne.com.au

Timmermann V, Børja I, Hietala AM, Kirisits T, Solheim H (2011) Ash dieback: pathogen spread and diurnal patterns of ascospore dispersal with special emphasis on Norway. EPPO Bull 41:14-20. doi:10. 1111/j.1365-2338.2010.02429.x

Tröltzsch K, Van Brusselen J, Schuck A (2009) Spatial occurrence of major tree species groups in Europe derived from multiple data sources. For Ecol Manag 257:294-302

Watt MS, Ganley RJ, Kriticos DJ, Manning LJ (2011) Dothistroma needle blight and pitch canker: the current and future potential distribution of two important diseases of Pinus species. Can J For Res 41:412-424

Wermelinger B (2004) Ecology and management of the spruce bark beetle Ips typographus - a review of recent research. For Ecol Manag 202:67-82

Wikler K, Storer AJ, Newman W, Gordon TR, Wood DL (2003) The dynamics of an introduced pathogen in a native Monterey pine (Pinus radiata) forest. For Ecol Manag 179:209-221

Wingfield MJ, Hammerbacher A, Ganley RJ, Steenkamp ET, Gordon TR, Wingfield BD, Coutinho TA (2008) Pitch canker caused by Fusarium circinatum - a growing threat to pine plantations and forests worldwide. Australas Plant Pathol 37:319-334

Withrow JR, Lundquist JE, Negron JF (2013) Spatial dispersal of Douglas-fir beetle populations in Colorado and Wyoming. ISRN For. doi:10.1155/2013/542380 